\title{
ORIGINAL SCIENTIFIC PAPER \\ ASSESSMENT OF THE ECONOMIC EFFICIENCY OF RESEARCH AND EDUCATIONAL CENTERS (RECS) IN BUILDING A FORECAST IMAGE OF THE REGION
}

\author{
STRYABKOVA A. Elena ${ }^{1}$, TITOVA N. Irina ${ }^{2}$,GLOTOVA S.Anastasia ${ }^{3}$, \\ DOBRODOMOVA N.Tatiana ${ }^{4}$, LYSHCHIKOVA V.Julia ${ }^{5}$
}

${ }^{1}$ Belgorod State University, Belgorod (RUSSIA)

${ }^{2}$ Belgorod State University, Belgorod (RUSSIA)

${ }^{3}$ Belgorod State University, Belgorod (RUSSIA)

${ }^{4}$ Belgorod State University, Belgorod (RUSSIA)

${ }^{5}$ Belgorod State University, Belgorod (RUSSIA)

E-mail: stryabkova@bsu.edu.ru

\begin{abstract}
The experience of the leading countries of the world shows that the definition of strategic directions of development, as well as the formation of programs for basic research and advanced applied development, is now mainly engaged in the state in close cooperation with academic and university science, the business environment and public organizations. In countries that are focused on permanently improving the quality of life of their citizens, strengthening their competitive positions, etc., considerable attention is paid to the problem of developing their scientific and educational potential, through the creation of research and educational centers (RECs). In connection with the creation of RECs, there is a need to assess the effectiveness of their functioning. Now, there is no scientifically based methodology for evaluating the effectiveness of the RECs functioning. The article discusses the tools for evaluating scientific research that can be used to analyze the effectiveness of RECs activities. The study proposed a method for integrating indicators of the region's development potentials and indicators of the effectiveness of research and educational centers, based on a comparison of trends in the region's development potentials and the performance indicators of RECs. On the basis of the proposed methodology, an assessment of the effectiveness of the world-class REC "Innovative Solutions in the Agro-industrial Complex" was carried out, according to the results of which it is possible to judge the impact of the REC's activities on the economic development of the region.
\end{abstract}

Keywords: scientific and educational centers, the effectiveness of scientific research, the development of the region, indicative indicators.

JEL: $I 20$

DOI: 10.5937/intrev2103107S

UDC: 005.336.1:[711.47:167

330.131.5

COBISS.SR-ID 55107849 


\section{INTRODUCTION}

In the context of globalization and innovative development of the economy, the integration of production, science and education at the regional level should become the driving force for the development of the region [1][2]. According to the global trends in economic development, within the framework of the national project "Science", world-class research and educational centers (RECs) are being created in the Russian regions, through which the region's economy can be adapted to the "new innovative" economy. Modern RECs include national research universities, secondary educational organizations (schools, lyceums), small, medium and large enterprises whose activities are aimed at commercializing the results of scientific and technical activities. It is RECs that implement the transfer of scientific results to the real sector of the economy, increasing the innovative potential and investment attractiveness of the region[3][4][5].Each Russian region is characterized by a functioning environment that has a high degree of differentiation in the territorial context. With the help of RECs, you can manage research activities at the regional level, considering the level of development of the region and its potential. Within the framework of our research, the economic potential of the region can be represented as a combination of the human, innovative, investment and digital potential of the region.

The creation and functioning of scientific and educational centers in the Russian Federation affects the economic development of the region, so there is a need to assess the economic effectiveness of the REC "Innovative Solutions in the Agro-industrial Complex" in the development of the region. Now, there is no specific methodology for evaluating the effectiveness of RECs. Scientific review of Russian and foreign literature [6][7][8][9][10][11][12] indicates a comprehensive approach to evaluating the effectiveness of research and educational centers, considering the evaluation of the effectiveness of scientific research that has an applied nature and is aimed at the production of high-tech products.

\section{RESEARCH METHODOLOGY}

So, the assessment of the economic efficiency of RECs should be systematic and consider the results of educational activities that have an impact on the human and innovative potential of the region. A qualitative indicator is the personnel potential of graduates, their demand in the regional labor market, as well as the production of high-tech products with significant knowledge intensity. It is important to note that it is necessary to measure the effectiveness of a research and educational center at all stages of its functioning (Figure 1) [13]. This allows us to move to an economy in which the human potential has a higher quality and determines the production of high-tech, high-tech products.

\begin{tabular}{|l|l|}
\hline Stage 1 & $\cdot$ Generating an idea \\
\hline Stage 2 & -Innovative training in the areas of idea production \\
\hline & Stage 4 \\
\hline
\end{tabular}

\section{Fig. 1.Stages of REC operation}

On the basis of the Decree of the Government of the Russian Federation of April 30, 2019 No. 537 "On measures of state support of world-class research and educational centers based on the integration of higher education and scientific organizations and their cooperation with organizations operating in the real sector of the economy" and Methodological recommendations for the formation of centers for the development of competencies of heads of scientific, scientific and technical projects and laboratories on the basis of world-class RECs, as well as the development of activity programs ("road maps") of centers for the development of competencies of heads of scientific, scientific and technical projects and laboratories, dated April 23, 2019, No. 3, the criteria for the effectiveness of RECs were established [14]. 
So, let's present a list of world-class REC performance indicators according to the stages of achieving results (Table 1):

- the number of patents for inventions in the areas determined by the priorities of scientific and technological development of the Russian Federation, registered in the Russian Federation and (or) having legal protection abroad (1);

- the volume of work performed and services, culminating in the production, preliminary and acceptance tests of the prototype (pilot batch) (2);

- the share the new and improved high-tech products in the total volume of shipped products (3);

- the number of articles in the areas defined by the priorities of scientific and technological development of the Russian Federation, scientific journals, indexed in the international databases Scopus and (or) Web of Science (for universities and research organizations) (4);

- the share of researchers in age from 39 years old in the total number of researchers (5);

- the share of workers of the organizations involved in the creation of a center, trained for additional vocational programs, in accordance with the directions of the center (6);

- the number of nonresident students in educational programs of higher education, who came from the subjects of the Russian Federation, not participating in the establishment of the center, as well as foreign students (7);

- the number of new high-tech jobs (8);

- the number of grants in the form of subsidies for the creation and modernization of scientific infrastructure for large-scale world-class scientific projects within the framework of the federal project "Development of advanced infrastructure for research and development in the Russian Federation" of the national project "Science" (9).

In the context of our research, it is necessary to assess the impact of the REC "Innovative Solutions in the Agro-industrial Complex" on the socio-economic development of the region, on the formation of its forecast image. As noted earlier, the forecast image of the region is formed considering the development of human, innovative, investment and digital potential in the region. Assessing the level of development of these potentials, we can talk about the direction of the vector of development of the region. We will focus on the theoretical justification of the assessment of each of the potentials, considering the REC "Innovative Solutions in the Agro-industrial Complex".

(I) Human potential - when evaluating it, we consider the qualitative component, i.e. the level of education of personnel in high-tech companies, as well as the number of people employed in the production of innovative high-tech products.

(II) Innovation potential - when evaluating it, we focus on the innovative activity of agribusiness organizations and the production of high-tech products in this area.

(III) Investment potential - the volume of investments in the fixed capital of companies producing high-tech products, as well as the volume of investments in specialized programs for attracting, training and developing personnel engaged in research and development, in addition, investments in updating the material and technical base at innovative enterprises of the agro-industrial complex should be taken into account.

(IV) Digital potential - should be considered when evaluating the introduction of digital technologies in innovative agricultural enterprises, in order to improve the efficiency of business processes.

In accordance with the indicators described above, the assessment of the economic efficiency of the REC "Innovative Solutions in the Agro-industrial Complex" will consist in comparing the performance indicators of the REC (level 1) and the indicators of socio - economic development of the region (level 2). Thus, we propose a two-level evaluation system (Table 1). 
Table 1. Comparison of REC performance indicators and regional development potentials

\begin{tabular}{|l|l|l|c|}
\hline \multicolumn{2}{|c|}{ Level 1 } & \multicolumn{2}{c|}{ Level 2 } \\
\cline { 1 - 2 } 1 & Number of patents & & In \\
\hline 2 & Creating a prototype & & \\
\hline 3 & Share of knowledge-intensive products & Human potential & I \\
\hline 4 & Number of articles & & \\
\hline 5 & Percentage of young research and teaching staff & & III \\
\cline { 1 - 2 } 6 & Quality of REC personnel reserve & Investment potential & IV \\
\hline 7 & Attracting nonresident and international students & & \\
\hline 8 & Number of new high-tech jobs & Digital potential & \\
\hline 9 & Number of grants & & \\
\hline
\end{tabular}

As can be seen from the Table 1, initially a link is established between the performance indicators of the REC "Innovative Solutions in the Agro-industrial Complex" and the dynamics of the economic potential of the region, which is determined by the accumulation of human, innovative, investment and digital potential.

Indicator (1) for the REC "the number of patents" is associated with the development of innovative activity of agricultural enterprises and other enterprises that are part of the world-class REC. Therefore, it will contribute to the development of innovative potential in the region on the one hand, and on the other hand, the patent activity of the region determines the quality of human potential, which should be represented by an intensive interaction of scientists and researchers.

Indicator (2) for the REC "the creation of a prototype" is the cost of work performed, services and goods produced for the reporting year, including depreciation deductions for the full restoration of fixed assets of organizations performing research and development. As a result of the production and testing of the prototype, the number of publications and the volume of high-tech products increases, which contributes to the development of science and high technologies in the region. Thus, indicator (2) is directly related to the investment potential of the region, as it increases the investment attractiveness of the region and the efficiency of investment in research and development, in addition, it affects the innovation potential of the region.

Indicator (3) for REC "the share of knowledge intensive products " is determined by the quality of human potential, the availability of highly qualified specialists in the region. As well as the share of new and improved high-tech products in the total volume of shipped products will be influenced by the investment potential of the region, which depends on the level of advanced equipment and technologies necessary to produce high-tech products. At the same time, analyzing the innovative potential of the region, the indicator "the share of high-tech products" is one of the defining indicators. Therefore, this indicator is interrelated with human, investment and innovation potential.

Indicator (4) for REC "the number of articles" depends on the development of priority high - tech industries, on the activities of scientific, scientific and technical projects and laboratories, and on the availability of researchers (researchers) with the necessary level of qualification and professionalism. Thus, the number of articles in the areas determined by the priorities of scientific and technological development of the Russian Federation in scientific publications indexed in the international databases Scopus and (or) Web of Science (for universities and scientific organizations) is comparable to the level of development of the human and innovative potential of the region.

Indicator (5) for the REC "the share of young research and teaching staff" will be determined by the innovative potential of the region, the activity of innovative processes at the enterprises included in the REC. On the other hand, young research and teaching staff working in RECs will provide an increase in the number of high-performance jobs and attract highly qualified specialists from other regions. The investment component will have a significant impact on this indicator, since scientific and technological production, in addition to the availability of young scientists, needs financial support. In this regard, innovation and investment potential are the determining factors for increasing the share of young scientists, which in turn affects the attraction and accumulation of human capital.

Indicator (6) for REC "the quality of REC personnel reserve" is calculated as the ratio of employees of organizations participating in the creation of the center who have successfully completed training under the CRCP programs in accordance with the directions of REC "Innovative Solutions in the Agro- 
industrial Complex" to the number of employees of all REC organizations. This indicator depends on the saturation of the education system with new personnel and is closely interrelated with the human potential of the region and contributes to the digitalization of the region's economy as part of the development of the direction "Digital transformation of the agro-industrial complex and resource conservation".

Indicator (7) for the REC "the number of nonresident and foreign students" provides a migration increase in the population of the Belgorod region, accumulating human potential. This indicator is a quantitative characteristic of human potential, but in the future, it is highly qualified personnel who can ensure the development of promising areas of the REC "Innovative Solutions in the Agro-industrial Complex".

Indicator (8) for REC "the number of new high-tech jobs" in high-tech industries will depend on the reserves of innovative development of the economy. It is also associated with the use of digital technologies and highly qualified personnel who participate in the development of REC areas. Consequently, there is a link between the REC performance indicator and innovation potential, digital potential, and human potential.

Indicator (9) for the REC "the number of grants" will depend on the effectiveness of the REC, since grants are provided based on the results of the REC "Innovative Solutions in Agriculture" in the form of subsidies for the creation and modernization of scientific infrastructure for the implementation of world-class projects. Thus, this indicator will be related to the investment in fixed assets, and the completion of the grant will depend on the quality of human potential.

The evaluation of the effectiveness of the REC "Innovative Solutions in the Agro-industrial Complex" in the formation of the forecast image of the region will be carried out according to the following algorithm (Figure 2).

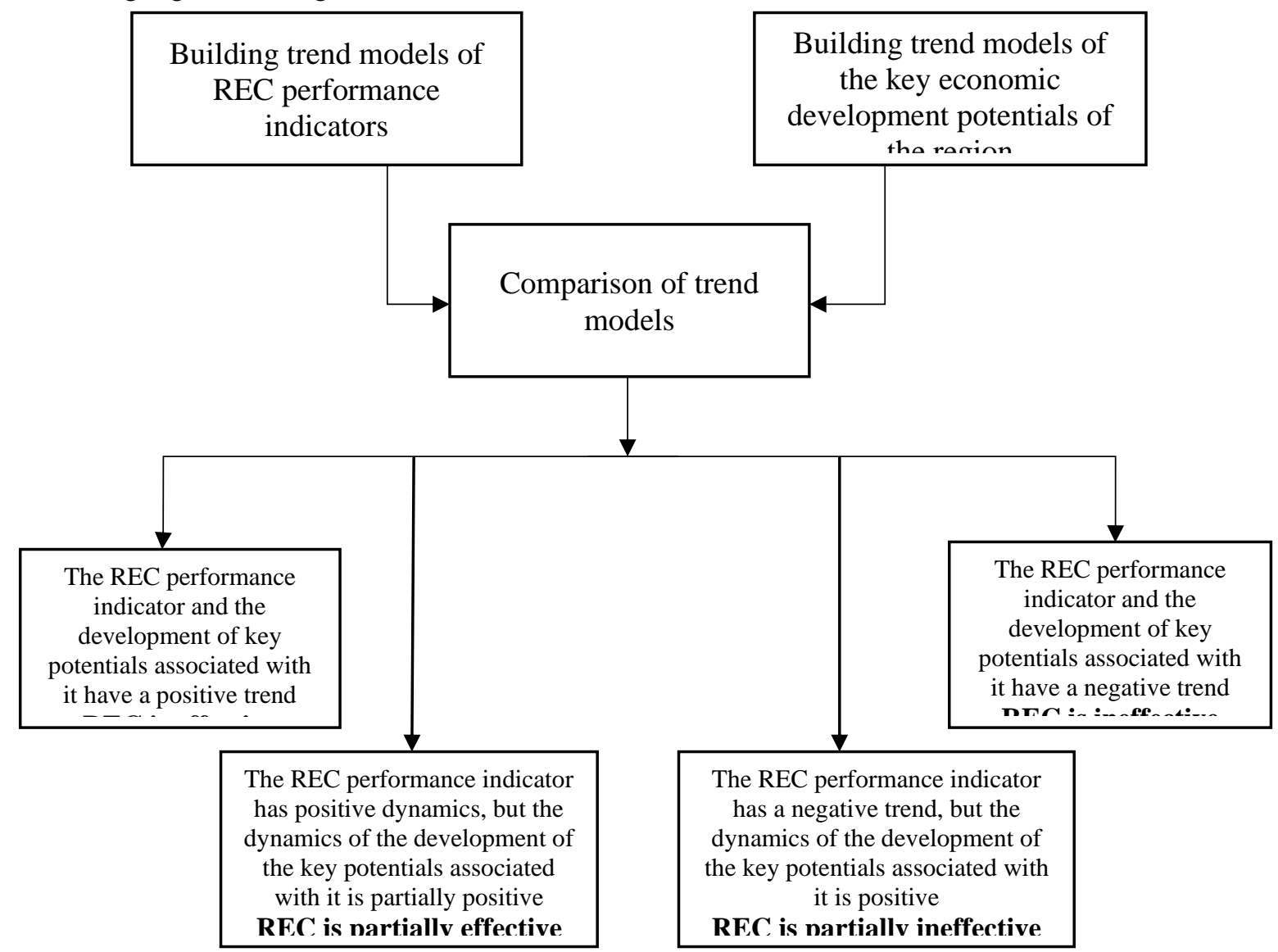

Fig. 2. Evaluation of REC performance indicators in the development of the region

So, it follows from the figure that initially we identify the annual trends for each potential that determine the reference model of the region and determine the trends in the development of the 
performance indicators of the scientific and educational center, which are interrelated with the potential of regional development. When comparing the identified trends, various alternatives can be observed.

If the performance indicator for RECs (indicated by circles in the figure) has a positive development dynamics and at the same time a positive trend in the associated potential of the region (for all potentials in the case of several related ones), then the REC for this indicator worked completely effectively in the reporting year.

If the performance indicator for the REC is characterized by positive dynamics, but the associated regional development potentials have partially positive, partially negative dynamics, then the REC for this indicator worked partially effectively in the reporting year. I.e., its assessment should be positive, but adjusted for the fact that the region in this direction (potential) is in the zone of negative dynamics and the REC could not change the situation. In this case, the REC will be interested in contributing to the positive regional dynamics in this area and take several management decisions.

If the performance indicator for the REC has a negative dynamic, but the dynamics of the associated potential (potentials) is positive (in the case of several potentials, there is a possibility of gradation), then the REC for this indicator worked partially inefficiently in the reporting year. I.e., the region for this potential in the current period was characterized by growth, and the work of the REC did not lead to a decrease in the pace of economic development, and, therefore, it needs to be adjusted under the given development conditions, without resorting to extreme measures.

If, finally, the performance indicator of the REC is characterized by a negative trend and the trend in the associated regional development potential (potentials) is also negative, then the REC for this indicator worked inefficiently in the reporting year (completely ineffective in the case of a negative trend in all related economic development potentials of the region, if there were several of them). In this case, it is necessary to develop several comprehensive measures to be taken within the framework of the REC "Innovative Solutions in the Agro-industrial Complex". Consequently, the economic efficiency of the regional REC "Innovative Solutions in Agro-industrial Complex" is associated with the efficiency of the region, reflecting the contribution of the REC.

\section{RESULTS AND DISCUSSION}

We will evaluate the effectiveness of the REC "Innovative Solutions in the Agro-industrial Complex " in building a forecast image of the region (Figure 3).
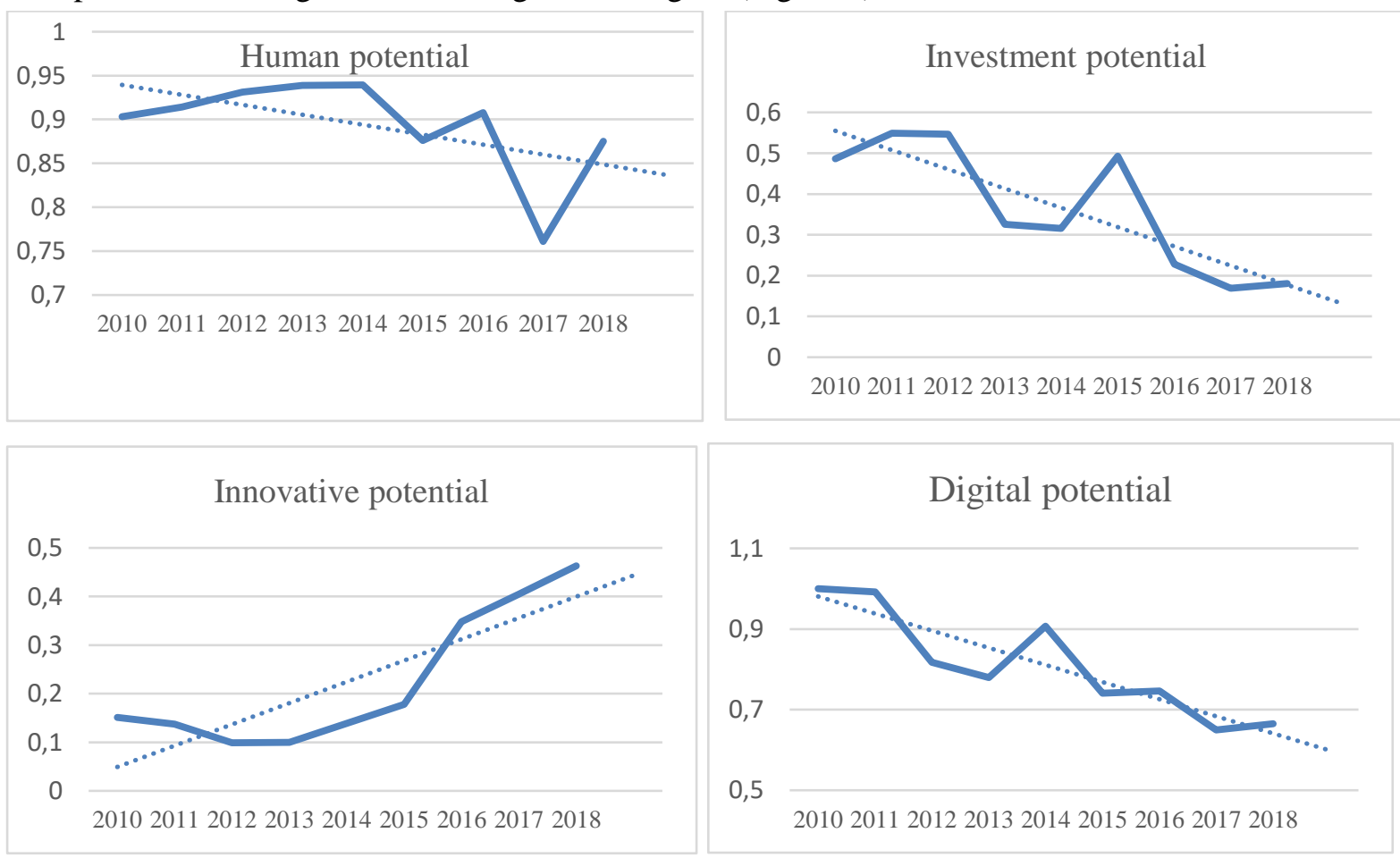

Fig. 3.Trends in the regional development potentials of the Belgorod Region for 2010-2018 
Figure 3 shows that the annual trends in human, investment, and digital potentials have an ambiguous trend, either of growth or decline. And only in terms of innovation potential, there is a steady growth trend.

We compare the identified trends with the performance indicators of research and educational centers in the matrix presented in Table 2.

Table 2. Matrix for evaluating the effectiveness of RECs

\begin{tabular}{|l|l|l|l|l|}
\hline $\begin{array}{l}\text { REC performance } \\
\text { potentials/ indicators }\end{array}$ & Human & Innovation & Investment & Digital \\
\hline Number of patents & & & & \\
\hline Creating a prototype & & & \\
\hline $\begin{array}{l}\text { Share of knowledge- } \\
\text { intensive products }\end{array}$ & & & \\
\hline Number of articles & & & \\
\hline $\begin{array}{l}\text { Share of young research } \\
\text { and teaching staff }\end{array}$ & & & \\
\hline $\begin{array}{l}\text { Quality of REC personnel } \\
\text { reserve }\end{array}$ & & & \\
\hline $\begin{array}{l}\text { Attracting nonresident and } \\
\text { international students }\end{array}$ & & & \\
\hline $\begin{array}{l}\text { Number of new high-tech } \\
\text { jobs }\end{array}$ & & & \\
\hline Number of grants & & \\
\hline - REC is effective & & & \\
\hline - the relationship between the indicators is absent or very weak & & \\
\hline
\end{tabular}

The results of the comparison are presented in Table 3.

Table 3. Results of the evaluation of the effectiveness of the REC "Innovative Solutions in the Agroindustrial Complex" in building a forecast image of the region

\begin{tabular}{|c|c|c|}
\hline REC Indicator & $\begin{array}{c}\text { Performance } \\
\text { evaluation }\end{array}$ & Interpretation of evaluation results \\
\hline $\begin{array}{l}\text { Number } \\
\text { patents }\end{array}$ & $\begin{array}{l}\text { Partially } \\
\text { effective }\end{array}$ & $\begin{array}{l}\text { Since the patent activity of the region is determined by the quality of } \\
\text { human potential, which should be represented by an intensive } \\
\text { interaction of scientists and researchers, therefore, within the framework } \\
\text { of the REC, it is necessary to strengthen cooperation in the field of } \\
\text { agriculture of scientists and researchers. This is primarily necessary for } \\
\text { the commercialization of patent applications. }\end{array}$ \\
\hline $\begin{array}{ll}\text { Creating } & \text { a } \\
\text { prototype }\end{array}$ & $\begin{array}{l}\text { Partially } \\
\text { effective }\end{array}$ & $\begin{array}{l}\text { Within the REC, it is necessary to develop the investment attractiveness } \\
\text { of the region and the efficiency of investment in the field of research } \\
\text { and development. }\end{array}$ \\
\hline $\begin{array}{l}\text { Share } \\
\text { knowledge- } \\
\text { intensive } \\
\text { products }\end{array}$ & $\begin{array}{l}\text { Partially } \\
\text { effective }\end{array}$ & $\begin{array}{l}\text { In order to increase efficiency, it is necessary to encourage highly } \\
\text { qualified specialists to develop innovative projects in the field of } \\
\text { agriculture, and secondly, to increase the investment potential of the } \\
\text { region for the production of high - tech products. }\end{array}$ \\
\hline $\begin{array}{l}\text { Number of } \\
\text { articles Scopus, } \\
\text { WoS }\end{array}$ & $\begin{array}{l}\text { Partially } \\
\text { effective }\end{array}$ & $\begin{array}{l}\text { To increase efficiency, it is important to develop research activities } \\
\text { within the REC, increasing the human potential of the region. }\end{array}$ \\
\hline $\begin{array}{l}\text { Share of young } \\
\text { research and } \\
\text { teaching staff }\end{array}$ & $\begin{array}{l}\text { Partially } \\
\text { effective }\end{array}$ & $\begin{array}{l}\text { To increase efficiency, it is necessary to activate investment processes } \\
\text { in the region and attract highly qualified specialists to the region in the } \\
\text { areas of development of the REC " Innovative solutions in the agro- } \\
\text { industrial complex» }\end{array}$ \\
\hline $\begin{array}{l}\text { Quality of REC } \\
\text { personnel } \\
\text { reserve }\end{array}$ & $\begin{array}{l}\text { Partially } \\
\text { effective }\end{array}$ & $\begin{array}{l}\text { To increase efficiency, it is necessary to improve the activities of the } \\
\text { Center for Human Resource Development, taking into account the } \\
\text { digitalization of the region's economy, as part of the development of the } \\
\text { direction "Digital transformation of the agro-industrial complex and } \\
\text { resource conservation". }\end{array}$ \\
\hline $\begin{array}{l}\text { Attracting } \\
\text { nonresident and } \\
\text { international } \\
\text { students }\end{array}$ & $\begin{array}{l}\text { Partially } \\
\text { effective }\end{array}$ & $\begin{array}{l}\text { It is necessary to create an appropriate standard of living in the region, } \\
\text { so that educated nonresident and foreign students, highly qualified } \\
\text { specialists have the opportunity to improve their human resources in the }\end{array}$ \\
\hline
\end{tabular}




\begin{tabular}{|l|l|l|}
\hline & & $\begin{array}{l}\text { Center for the Development of Human Resources and within the REC } \\
\text { they should be provided with high-tech jobs. }\end{array}$ \\
\hline $\begin{array}{l}\text { Number of new } \\
\text { high-tech jobs } \\
\text { effective }\end{array}$ & $\begin{array}{l}\text { In each direction of development of the REC "Innovative Solutions in } \\
\text { the Agro-industrial Complex", high-tech jobs should be created, which } \\
\text { should be provided for highly qualified specialists who have } \\
\text { successfully completed training under the relevant programs of the } \\
\text { Center for Human Resource Development. }\end{array}$ \\
\hline $\begin{array}{l}\text { Number of } \\
\text { grants }\end{array}$ & $\begin{array}{l}\text { Partially } \\
\text { effective }\end{array}$ & $\begin{array}{l}\text { It is necessary to increase the efficiency of the REC "Innovative } \\
\text { Solutions in the Agro-industrial Complex", since grants are provided } \\
\text { based on the results of the REC's activities. }\end{array}$ \\
\hline
\end{tabular}

\section{CONCLUSION}

As a result of the evaluation of the effectiveness of the REC in the formation of the forecast image of the region, it can be noted that all the indicators worked "partially effectively", which in principle is explained by the duration of the scientific and educational center-1 year. In the future, if the calendar plan of activities for the implementation of the activities of the center "Innovative Solutions in the Agroindustrial Complex" and the positive dynamics of the target indicators of the REC is observed, it is possible to increase the effectiveness of the REC "Innovative Solutions in the Agro-industrial Complex" in the formation of the forecast image of the Belgorod region. It is important to note that in the event of a slowdown in the growth rate of targets or their negative trend, it is necessary to develop a number of specific proposals that optimize and regulate the activities of the REC "Innovative Solutions in the Agro-industrial Complex".

\section{ACKNOWLEDGEMENT}

The study was carried out within the framework of an intra-university grant of the National Research University "BelSU" in accordance with Order No. 826-OD of 14.08.2020, the theme of the project "Smart specialization in the agro-industrial complex of the region: digital transformation and convergent technologies".

\section{REFERENCES}

[1] Zakharova, V. V. 2020. Scientific and educational center as a tool for the development of neoindustrial specialization of the regions of Russia. Creative Economy, 14(5): 763-774.

[2] Mazzucato, M. 2011. The Entrepreneurial State: Debunking Public vs. Private Sector Myths. London: Anthem Press. 266 p.

[3] Zakharova, V. V., 2019. Influence of the scientific and educational center on the acceleration of the industrial development of the region's economy. Science and Business: Ways of Development, 8: 116-119.

[4] Rastvortseva, S. N., 2020. Innovative way of changing the trajectory of the previous development of the region's economy. Economy of Region, 16(1): 28-42.

[5] Romanova, O. A., Sirotin, D. V., 2017. The image of the desired future of the economy of the industrial region: development trends and evaluation methodology. Economy of Region, 13(3): 746-763.

[6] Grebenyuk, I. I., Kiseleva, V. V., Troitskaya, A. A., 2015. Significance and prospects of development of the regional scientific and educational center in the Nizhny Novgorod region. Management of economic systems: electronic scientific journal, 2 (74). Access mode: https://cyberleninka.ru/article/n/znachenie-i-perspektivy-razvitiya-regionalnogo-nauchnoobrazovatelnogo-tsentra-v-nizhegorodskom-regione

[7] ANVUR, 2019. Italian National Agency for the Evaluation of Universities and Research Institutes. URL: https://rio.jrc.ec.europa.eu/en/organisations/national-agency-evaluation-university-andresearch-sys-tem-anvur.

[8] Kelof, D., 2018. Improving the efficiency of innovative activity of companies. Foresight, 12(3): 30-33. 
[9] Dezhina, I.G., 2017. Science and Innovation Policy of the Russian Government: A variety of instruments with uncertain outcomes? Public Administration Issues. Special Issue (electronic edition), 5: 7-26.

[10] Gohberg, L. \& Roud, V., 2015. Structural Changes in the National Innovation Systems: Longitudinal study of innovation modes in Russian industry. Economic Change and Restructuring, 49(2-3): 269-288.

[11] Lundvall, B.-A. (ed)., 1992. National Systems of Innovation: Towards a theory of innovation and interactive learning. London: Pinter Publ. 291 p.

[12] Barabashev, A. G., Makarov, A. A., Makarov, I. A., 2019. On improving indicative assessments of the quality of public administration. Issues of state and municipal administration, 2: 7-38

[13] Falkov, V. N., Tolstikov, A.V., Latyshev, A. S., Barabashev, A. G., 2019. On the possibilities of improving the evaluation of the effectiveness of scientific and educational centers (REC): indicative approach. Management of science: theory and practice, 1(2): 15-37. DOI: https://doi.org/10.19181/smtp.2019.1.2.1

[14] Resolution of the Government of the Russian Federation of April 30, 2019, No. 537 "On measures of State support for world-class research and education Centers based on the integration of higher education and research organizations and their cooperation with organizations operating in the real sector of the economy".

https://www.garant.ru/products/ipo/prime/doc/72140532/

\section{Article history:}

Received 10 August 2021

Accepted 30 November 2021 